\title{
Pengaruh Penjualan dan Biaya Operasional terhadap Laba Bersih PT Indocement Tunggal Prakarsa (Persero) Tbk Periode 2010-2017
}

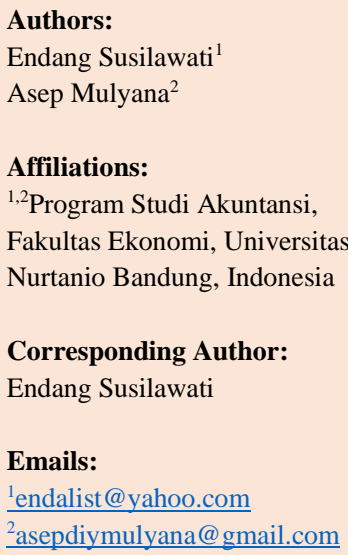

Article History:

Received: September 20, 2018 Revised : November 29, 2018 Accepted: December 08, 2018

How to cite this article: Susilawati, E., \& Mulyana, A. (2018). Pengaruh Penjualan dan Biaya Operasional terhadap Laba Bersih PT Indocement Tunggal Prakarsa (Persero) Tbk Periode 2010-2017. Organum: Jurnal Saintifik Manajemen dan Akuntansi, 1(2), 74-87. doi: https://doi.org/10.35138/organu $\underline{\text { m.v1i2 } 2.33}$

Journal Homepage: ejournal.winayamukti.ac.id/ind ex.php/Organum

\section{Copyright:}

(C) 2018. Published by Organum: Jurnal Saintifik Manajemen dan Akuntansi. Faculty of Economics and Business. Winaya Mukti University.
Abstract. This study aims to determine the influence of sales and operational costs on the net income both partially and simultaneously of PT Indocement Tunggal Prakarsa, Tbk. from 2010 to 2017. The type of research was descriptive verification by quantitative methods. Based on the results of the research showed that the sales and operational costs influence the net income simultaneously. Partially, sales and operational costs influenced on the net income.

\section{Keywords: Sales; operational costs; net income.}

Abstrak. Penelitian ini bertujuan untuk mengetahui pengaruh penjualan dan biaya operasional terhadap laba bersih secara parsial dan simultan pada PT Indocement Tunggal Prakarsa (Persero) Tbk dengan mengambil data laporan keuangan PT Indocement Tunggal Prakarsa (Persero) Tbk periode 2010-2017. Metode penelitian yang digunakan dalam penelitian ini adalah metode kuantitatif dengan jenis penelitian deskriptif verifikatif. Berdasarkan hasil penelitian menunjukkan bahwa penjualan dan biaya operasional secara simultan berpengaruh terhadap laba bersih. Secara parsial penjualan dan biaya operasional berpengaruh terhadap laba bersih.

Kata kunci: Penjualan; biaya operasional; laba bersih.

\section{Pendahuluan}

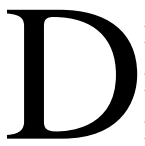
idirikannya sebuah perusahaan pada umumnya mempunyai suatu tujuan. Tujuan tersebut yaitu untuk memperoleh laba yang sebesar-besarnya demi menjaga kelangsungan hidup perusahaan. Hal ini agar segala kegiatan dalam perusahaan dapat berlangsung dengan baik sehingga mampu bersaing dengan perusahaan-perusahaan yang sejenis. Di era globalisasi sekarang ini tingkat persaingan sangat tinggi sehingga hanya badan usaha yang memiliki kinerja atau performa yang baik yang akan bertahan. Dalam persaingan usaha yang semakin kompetitif perusahaan dituntut untuk semakin efisien dalam menjalankan aktivitasnya, terlebih dalam kondisi ekonomi saat ini yang penuh ketidakpastian dan krisis ekonomi yang melanda Indonesia sangat berat serta merusak berbagai sektor dan perekonomian, sehingga perlu mengoptimalkan sumber daya yang dimiliki (Wisesa, Zukhri, \& Suwena, 2014).

Dalam mencapai laba perusahaan tidak akan lepas dari penjualan serta biaya, termasuk biaya operasional. Laba bersih berasal dari transaksi pendapatan, beban, keuntungan, dan kerugian. Transaksi ini diikhtisarkan dalam laporan laba rugi. Laba dihasilkan dari selisih antara sumber daya masuk (penda- 
patan dan keuntungan) dengan sumber daya keluar (beban dan kerugian) (Hery, 2013:46). Penjualan dan biaya sangatlah berpengaruh terhadap laba bersih, penjualan yang meningkat, serta biaya yang efisien, mestinya berpengaruh terhadap peningkatan laba yang diperoleh perusahaan dan demikian juga sebaliknya (Butar, 2019). Hubungan yang kompleks dikemukakan oleh Wisesa, Zukhri, \& Suwena (2014) yang menyatakan bahwa volume penjualan yang meningkat, biaya yang efisien, dan laba bersih yang diperoleh secara meningkat maka akan membawa keuntungan yang sangat besar bagi perusahaan.

PT Indocement Tunggal Prakarsa (Persero) Tbk merupakan salah satu produsen semen di Indonesia yang didirikan sejak 16 Januari 1985 dan salah satu produsen semen yang terbesar di Indonesia. Setelah dilakukan observasi awal terhadap PT tersebut terlihat adanya penurunan pada laba bersih, dengan laba bersih PT Indocement Tunggal Prakarsa (Persero) Tbk pada tahun 2012 sebesar Rp 4.763.388,00 miliar pada tahun 2013 turun menjadi Rp 5.012.294,00 miliar, demikian juga yang terjadi pada tahun 2015 yang laba bersih mengalami penurunan sebesar Rp 4.356.661,00 miliar dari tahun 2014 dengan pendapatan laba sebesar $\mathrm{Rp}$ 5.293.416,00 miliar.

PT Indocement Tunggal Prakarsa (Persero) Tbk mencatatkan penurunan laba bersih sebesar Rp 2,01 triliun pada 2017. Angka tersebut turun sebesar 51,9 persen dibandingkan periode yang sama di tahun sebelumnya (economy.okezone.com, 2018). Diduga gagalnya PT Indocement Tunggal Prakarsa (Persero) Tbk, turunnya laba bersih disebabkan oleh beban perusahaan meningkat signifikan pada pos bahan bakar, biaya listrik, bahan baku, dan biaya pengepakan (www.cnbcindonesia.com, 2017). Sedangkan, turunnya penjualan menurut Oey Marcos Corporate Secretary, PT Indocement Tunggal Prakarsa (Persero) Tbk, karena meningkatnya persaingan di pasar yang tengah mengalami kelebihan pasokan, turunnya permintaan, serta penambahan beberapa pabrikan dan penggilingan semen di Home Market, yang menyebabkan terkikisnya marjin sehingga terjadinya penurunan harga.

Berdasarkan permasalahan yang dihadapi PT Indocement Tunggal Prakarsa (Persero) Tbk mengenai penurunan laba bersih yang berlangsung selama 4 tahun terakhir membuat perusahaan gagal untuk menaikkan penjualan serta menekan biaya produksi dan beban operasionalnya. Oleh karena itu, perlu diadakan penelitian mengenai "Pengaruh Penjualan dan Biaya Operasional terhadap Laba Bersih PT Indocement Tunggal Prakarsa (Persero) Tbk Periode 2010-2017'. Adapun tujuan dari penelitian ini adalah untuk mengetahui pengaruh penjualan dan Biaya Operasional terhadap Laba Bersih pada PT Indocement Tunggal Prakarsa (Persero) Tbk Periode 2010-2017 baik secara parsial maupun simultan.

\section{Kajian Literatur}

\section{Penjualan}

Moekijat (2014:288) menyatakan bahwa penjualan (selling) merupakan suatu kegiatan yang ditujukan untuk mencari pembeli, memengaruhi dan memberi petunjuk agar pembeli dapat menyesuaikan kebutuhannya dengan produksi yang ditawarkan, serta mengadakan penawaran mengenai harga demi menguntungkan bagi kedua belah pihak. Sejalan dengan pendapat itu Tjiptono (2012:310) mengemukakan bahwa penjualan adalah sumber pendapatan yang diperlukan menutup ongkos-ongkos dengan harapan mendapatkan laba. Definisi lain juga mengatakan bahwa penjualan adalah pendapatan yang berasal dari penjualan produk perusahaan, disajikan setelah dikurangi potongan penjualan dan retur penjualan (Sulistyowati, 2010:270). Adapun Indikator penjualan menurut 
Sulistyowati (2010:270) dinyatakan dengan rumus sebagai berikut :

\section{Penjualan $=$ Penjualan Barang/Jasa - Pemotongan Penjualan - Retur Penjualan}

Hasil penelitian Akbar \& Astuti (2017) menyatakan bahwa penjualan berpengaruh pada laba bersih, dan ketika penjualan meningkat maka laba bersih akan ikut meningkat pula, sedangkan ketika penjualan menurun maka laba bersih akan ikut turun. Satwika, Hendratno, \& Zultilisna (2018) juga berpendapat sama yaitu terdapat pengaruh yang signifikan antara arah negatif dan penjualan bersih terhadap laba bersih. Berdasarkan teori dan hasil penelitian terdahulu maka dirumuskan hipotesis sebagai berikut;

$\mathrm{H}_{1}$ : Penjualan berpengaruh terhadap laba bersih.

\section{Biaya Operasional}

Menurut Murhadi (2013:37) biaya operasional (operating expense) merupakan biaya yang terkait dengan operasional perusahaan dan administrasi (selling and administrative expense), biaya iklan (advertising expense), biaya penyusutan (depreciation and amortization expense), serta perbaikan dan pemeliharaan (repair and maintenance expense). Pendapat tersebut dipersingkat oleh Jusuf (2014:41) yang menyatakan, biaya operasional adalah biaya yang tidak berkaitan dengan urusan produksi, melainkan biaya aktivitas operasional perusahaan sehari-hari. Selain itu, biaya operasional sering disebut juga SGA (Selling, General, and Administration Expenses). Sedangkan, menurut Rudianto (2013:17) biaya operasional adalah komponen biaya perusahaan di luar biaya produksi. Menurut Widilestariningtyas et. al. (2012:13), biaya operasional dinyatakan dengan rumus :

\section{Biaya Operasional $=$ Biaya Pemasaran/Penjualan + Biaya Administrasi dan Umum}

Hasil penelitian Risyana \& Suzan (2018) membuktikan bahwa biaya operasional berpengaruh terhadap laba bersih, yang mengatakan apabila semakin tinggi biaya operasional yang ada di perusahaan maka laba bersih akan mengalami penurunan begitupun sebaliknya. Hasil penelitian Manda (2018) juga membuktikan bahwa biaya operasional memiliki pengaruh yang signifikan terhadap laba bersih. Dari teori dan hasil penelitian sebelumnya maka dirusmuskan hipotesis sebagai berikut; $\mathrm{H}_{1}$ : Biaya operasional berpengaruh terhadap laba bersih.

\section{Laba Bersih}

Menurut Kasmir (2014:303) laba bersih (net profit) adalah laba yang telah dikurangi biaya-biaya yang menjadi beban perusahaan dalam suatu periode tertentu termasuk pajak. Sejalan dengan pendapat Kasmir, menurut Sasongko, dkk (2015:157) menyatakan, laba bersih adalah keuntungan yang diperoleh oleh perusahaan setelah dikurangi dengan pajak penghasilan. Laba bersih dihitung sebagai hasil pengurangan antara laba sebelum pajak dengan beban pajak penghasilan (Hery, 2016:199). Laba bersih dapat dihitung dengan rumus sebagai berikut: 


\section{Laba bersih = Laba sebelum pajak - pajak penghasilan}

Hasil penelitian Wisesa, Zukhri, \& Suwena (2014) menyatakan, volume penjualan dan biaya operasional mempunyai pengaruh terhadap laba bersih. Hal itu untuk meningkatkan laba bersih, maka volume penjualan pada suatu perusahaan harus meningkat dan biaya harus efisien serta biaya tersebut harus lebih tinggi dari pendapatan yang diperoleh. Penelitian Fitrihartini (2016) juga membuktikan bahwa secara bersama- sama berkontribusi terhadap perubahan perolehan laba bersih. Dengan demikian, dari teori dan penelitian terdahulu dapat dirumuskan hipotesis penelitian sebagai berikut;

$\mathrm{H}_{3}$ : Penjualan dan biaya produksi berpengaruh terhadap laba bersih.

Secara konseptual uraian tersebut dapat dilihat pada gambar berikut:

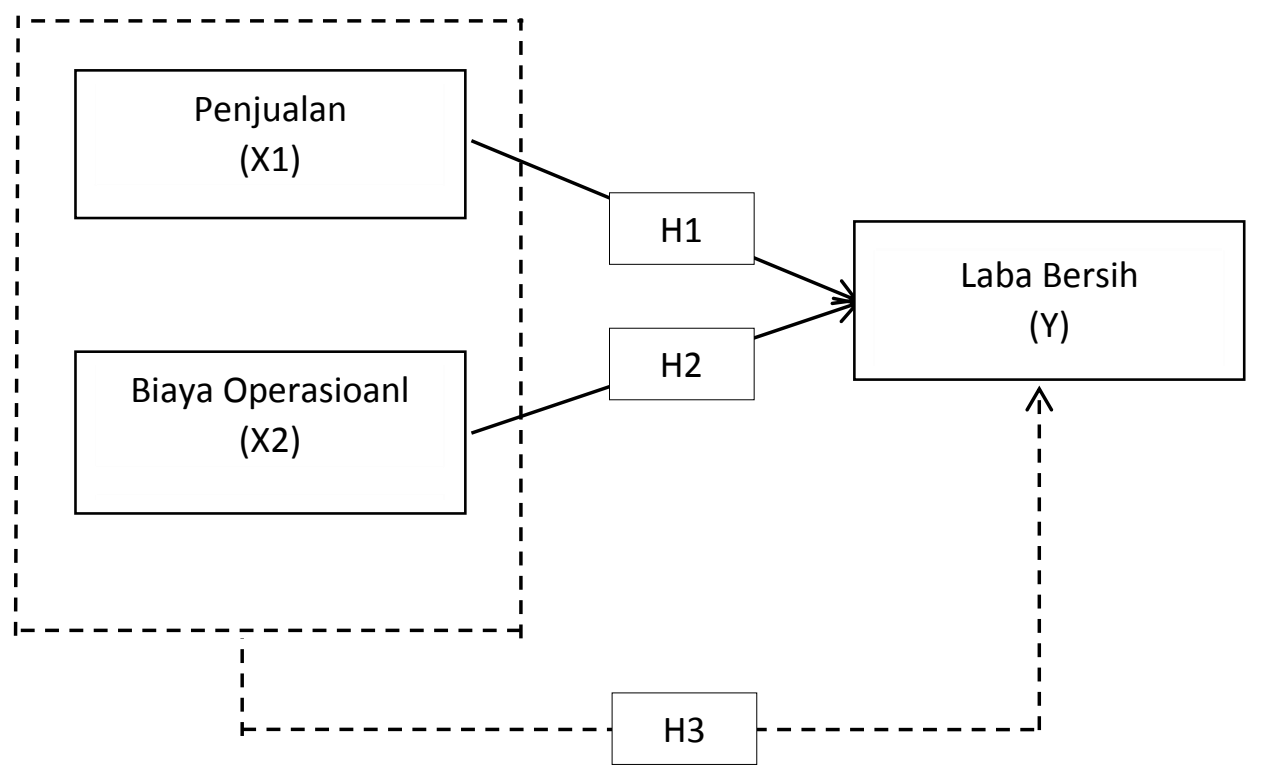

Keterangan :

$\longrightarrow$ : Berpengaruh secara parsial $------->$ : Berpengaruh secara simultan

\section{Metode Penelitian}

Menurut Sugiyono (2017:1) metode penelitian dapat diartikan sebagai cara ilmiah yang dilakukan untuk mendapatkan data yang objektif, valid, dan variabel dengan tujuan dapat ditemukan, dapat dibuktikan dan dapat dikembangkan suatu pengetahuan untuk memahami, memecahkan dan mengantisipasi masalah.

\section{Jenis Penelitian}

Jenis penelitian ini menggunakan penelitian deskriptif verifikatif dengan metode pendekatan kuantitatif. Sugiyono (2017:35) menyatakan, pengertian metode deskriptif adalah metode penelitian yang dilakukan untuk mengetahui keberadaan variabel mandiri, baik hanya pada satu variabel atau lebih (variabel yang berdiri sendiri atau variabel bebas) tanpa membuat perbandingan variabel itu sendiri dan mencari hubungan dengan variabel lain. Sugiyono (2017:8) metode verifikatif adalah penelitian yang dilakukan terhadap populasi atau sampel 
tertentu dengan tujuan untuk menguji hipotesis yang telah ditetapkan.

Pengertian metode penelitian kuantitatif dapat diartikan sebagai metode penelitian yang berlandaskan pada filsafat positivisme, digunakan untuk meneliti pada populasi atau sampel tertentu, pengumpulan data menggunakan instrumen penelitian, analisis data bersifat kuantitatif/statistik, dengan tujuan untuk menguji hipotesis yang telah ditetapkan.

\section{Unit Analisis}

Menurut Ghozali (2016:92) unit analisis berkaitan dengan tingkat agresi data dikumpulkan sebelum dianalis. Unit analisis pada penelitian ini adalah laporan keuangan tahunan (annual report) PT Indocement Tunggal Prakarsa (Persero) Tbk.

\section{Operasionalisasi Variabel}

Variabel dalam penelitian ini adalah penjualan (X1) dan biaya operasional (X2) sedangkan laba bersih (Y) sebagai variabel bebas. Menurut Sugiyono (2017:59) variabel bebas merupakan variabel yang memengaruhi atau menjadi sebab perubahannya atau timbulnya variabel terikat, sedangkan variabel terikat adalah variabel yang dipengaruhi atau yang menjadi akibat. Penelitian ini menggunakan skala rasio, sebagai suatu skala pengukuran yang mempunyai nilai nol mutlak dan mempunyai jarak yang sama (Riduwan, 2013:15).

\section{Sumber Data}

Sumber data dalam penelitian ini adalah data sekunder. Data sekunder ini merupakan informasi yang dikumpulkan oleh orang lain bukan oleh peneliti dalam melaksanakan penelitian (Ghozali, 2017:94). Dalam penelitian ini menggunakan data sekunder berupa laporan keuangan tahunan (annual report) PT Indocement Tunggal Prakarsa (Persero) Tbk.

\section{Teknik Pengumpulan Data}

Teknik pengumpulan data pada penelitian ini diperoleh dengan mengakses dari situs website www.idx.co.id berupa laporan keuangan dan tahunan (annual report) PT Indocement Tunggal Prakarsa (Persero) Tbk periode 2010-2017. Menurut Sugiyono (2017:224), teknik pengumpulan data merupakan langkah yang paling strategis dalam penelitian, karena tujuan utama dalam penelitian adalah mendapatkan data.

\section{Tenik Analisis Data}

Sugiyono (2017:244) menyatakan analisis data adalah proses mencari dan menyusun secara sistematis data yang diperoleh dari hasil wawancara catatan lapangan dan bahan-bahan lain, sehingga dapat mudah dipahami, dan temuannya dapat dikonfirmasi kepada orang lain.

\section{Uji Statistik Deskriptif}

Pada penelitian ini menggunakan analisis statistik deskriptif. Statistik deskriptif memberikan gambaran atau deskripsi suatu data yang dilihat dari nilai rata-rata (mean), standar deviasi, varian, maksimum, minimum, sum, range, kurtosis dan skewness (kemencengan distribusi) (Ghozali, 2016:19).

\section{Uji Asumsi Klasik}

Uji asumsi klasik pada penelitian ini menggunakan pengujian data berupa uji normalitas, uji autikorelasi, uji multikolinearitas, uji heteroskedastisitas. Menurut Ghozali (2017:19) uji asumsi klasik dilakukan bertujuan untuk menguji data-data yang digunakan dalam penelitian ini apakah telah memenuhi asumsi klasik yaitu data berdistribusi normal, tidak terjadi gejala multikolinearitas, tidak terdapat autokorelasi dan tidak terjadi gejala heteroskedastisitas. Menurut Kurniawan (2014:156), uji asumsi klasik merupakan persyaratan statistik yang harus dipenuhi pada analisis regresi linear berganda yang berbasis Ordinary Least Square $(O L S)$.

Untuk menganalisis data dan pengujian hipotesis dalam penelitian ini, menggunakan program Software IBM SPSS 25. 


\section{Uji Korelasi}

Untuk uji korelasi digunakan uji korelasi Pearson, menurut Sujarweni (2015:139) uji korelasi bertujuan untuk menguji hubungan antara dua variabel yang dapat dilihat dengan tingkat signifikan, jika ada hubungannya maka akan dicari seberapa kuat hubungan tersebut. Keeratan hubungan ini dinyatakan dalam bentuk koefisien korelasi.

\section{Uji Koefisien Determinasi $\left(\mathbf{R}^{2}\right)$}

Uji koefisien determinasi $\left(\mathrm{R}^{2}\right)$ dilakukan untuk mengukur seberapa jauh kemampuan model dalam menerangkan variasi variabel dependen (Ghozali, 2017:97).

\section{Uji Regresi Linier Berganda}

Selanjutnya dilakukan uji regresi linier berganda, menurut Ghozali (2017:19) regresi linear berganda ingin menguji pengaruh dua atau lebih variabel independen (explanatory) terhadap satu variabel dependen. Rumus persamaan regresi linear berganda menurut Sugiyono (2017:276) sebagai berikut:

$\mathrm{Y}=\alpha+\mathrm{b}_{1} \mathrm{x}_{1}+\mathrm{b}_{2} \mathrm{x}_{2}$

Keterangan :

$\mathrm{Y}=$ Variabel dependen

$\mathrm{X}_{1}$ dan $\mathrm{X}_{2}=$ Variabel independen

$\alpha \quad=$ Konstanta $\mathrm{b}_{1} \mathrm{~b}_{2} \quad=$ Koefisien regresi

Uji Hipotesis

\section{Uji Parsial (Uji t)}

Uji signifikan dengan uji t (parsial) diperlukan untuk menguji pengaruh antara variabel $\mathrm{X}_{1}$ dengan $\mathrm{Y}$ dan hubungan antara variabel $\mathrm{X}_{2}$ dengan $\mathrm{Y}$. Pengujian ini dilakukan dengan 2 arah (2 tail) dengan tingkat keyakinan $95 \% \quad(\alpha=0,05)$ dan dilakukan uji tingkat signifikan pengaruh antara hubungan variabel independen terhadap variabel dependen secara individual, dimana tingkat signifikansi ditentukan sebesar 5\% dan degree of freedom $(\mathrm{df})=\mathrm{n}-\mathrm{k}$.

\section{Uji Simultan (Uji F)}

Menurut Ghozali (2017:22) uji statistik $\mathrm{F}$ pada dasarnya menunjukkan apakah semua variabel independen yang dimasukkan dalam model mempunyai pengaruh secara keseluruhan terhadap variabel dependen, uji $\mathrm{F}$ ini dilakukan dengan cara membandingkan thitung dengan tabel. Sebelum membandingkan nilai $\mathrm{F}$ harus menentukan terlebih dahulu tingkat kepercayaan (1- $\alpha)$ dan derajat kebebasan (degree of freedom) df $1=\mathrm{k}-1$ dan df $2=n-k$ sehingga dapat menentukan nilai kritisnya dengan nilai alpha sebesar 0,05 .

\section{Hasil dan Pembahasan}

Hasil Penelitian Analisis Deskriptif

Tabel 1. Descriptive Statistics

\begin{tabular}{cccc}
\hline Minimum & Maximum & Mean & Std. Deviation \\
\hline 11137805 & 19996264 & 16074343,00 & 2904113,369 \\
\hline 1520732 & 3226452 & 2566722,75 & 567869,957 \\
\hline 1859818 & 5293416 & 3997761,63 & 1118972,585 \\
\hline
\end{tabular}

Sumber: Data Olahan SPSS 25

Dari hasil Tabel 1 hasil pengujian deskriptif menunjukkan bahwa variabel penjualan dengan jumlah data $(\mathrm{N})$ sebanyak 8, memiliki nilai minimum 11.137.805, nilai maksimum 19.996.264, dan nilai mean (rata-rata) 16.074.343,00 dengan standar deviasi 2.904.113,369. Variabel biaya produksi memiliki nilai minimum 1.520.732, nilai maksimum 3.226.452, dan nilai mean (rata-rata) 2.566.722,75 dengan standar deviasi 567.869,957. Variabel laba bersih memiliki nilai minimum 1.859 .818 , nilai maksimum 5.293.416 dan nilai mean (rata-rata) 3.997.761,63 dengan standar deviasi 1.118.972,585. 


\section{Hasil Uji Asumsi Klasik}

\section{Uji Normalitas}

Tabel 2. Uji Normalitas dengan One-Sample Kolmogorov-Smirnov Test

\begin{tabular}{|c|c|c|c|c|}
\hline & & Penjualan & $\begin{array}{c}\text { Biaya } \\
\text { Operasional } \\
\end{array}$ & Laba Bersih \\
\hline $\mathrm{N}$ & & 8 & 8 & 8 \\
\hline \multirow[t]{2}{*}{ Normal Parameters ${ }^{\mathrm{a}, \mathrm{b}}$} & Mean & $\begin{array}{r}16074343,0 \\
0\end{array}$ & 2566722,75 & 3997761,63 \\
\hline & $\begin{array}{l}\text { Std. } \\
\text { Deviation }\end{array}$ & $\begin{array}{r}2904113,36 \\
9\end{array}$ & 567869,957 & $\begin{array}{r}1118972,58 \\
5\end{array}$ \\
\hline \multirow{3}{*}{$\begin{array}{l}\text { Most Extreme } \\
\text { Differences }\end{array}$} & Absolute &, 162 & ,204 &, 128 \\
\hline & Positive & ,097 &, 123 &, 123 \\
\hline & Negative &,- 162 &,- 204 &,- 128 \\
\hline Test Statistic & & ,162 & ,204 & ,128 \\
\hline Asymp. Sig. (2-tailed) & & $200^{\mathrm{c}, \mathrm{d}}$ & $200^{\mathrm{c}, \mathrm{d}}$ & $200^{\mathrm{c}, \mathrm{d}}$ \\
\hline
\end{tabular}

Sumber: Data Olahan SPSS 25

Dari Tabel 2 hasil uji KolmogorovSmirnov dapat disimpulkan bahwa nilai signifikansi sebesar untuk penjualan, biaya operasional, dan laba bersih adalah 0,200 , ketiganya menunjukkan > 0,05 sehingga memenuhi asumsi normalitas atau dapat dikatakan data berdistribusi normal.

\section{Uji Multikolinearitas}

Berdasarkan Tabel 3 dapat diketahui bahwa nilai tolerance 0,434 dan VIF penjualan sebesar 2,305, biaya operasional 0,434 dan VIF 2,305, hasilnya menunjukkan tolerance value $>0,10$ atau VIF < 10 maka tidak terjadi multikolinearitas pada variabel penelitian.

Tabel 3. Uji Multikolinearitas Coefficients ${ }^{\mathrm{a}}$

\begin{tabular}{|c|c|c|c|c|c|c|c|}
\hline \multirow[b]{2}{*}{ Model } & \multicolumn{2}{|c|}{$\begin{array}{l}\text { Unstandardized } \\
\text { Coefficients }\end{array}$} & \multirow{2}{*}{$\begin{array}{l}\text { Standardiz } \\
\text { ed } \\
\text { Coefficien } \\
\text { ts } \\
\text { Beta }\end{array}$} & \multirow[b]{2}{*}{$\mathrm{t}$} & \multirow[b]{2}{*}{ Sig. } & \multicolumn{2}{|c|}{$\begin{array}{l}\text { Collinearity } \\
\text { Statistics }\end{array}$} \\
\hline & $\mathrm{B}$ & $\begin{array}{c}\text { Std. } \\
\text { Error }\end{array}$ & & & & $\begin{array}{c}\text { Toleran } \\
\text { ce }\end{array}$ & VIF \\
\hline $\begin{array}{ll} & (\text { Constant })\end{array}$ & $\begin{array}{r}- \\
436785,45 \\
9\end{array}$ & $\begin{array}{r}730372,4 \\
13\end{array}$ & &,- 598 & $\begin{array}{r}, 57 \\
6\end{array}$ & & \\
\hline Penjualan &, 553 & ,068 & 1,435 & $\begin{array}{r}8,16 \\
6 \\
\end{array}$ & $\begin{array}{r}, 00 \\
0\end{array}$ & ,434 & $\begin{array}{r}2,30 \\
5\end{array}$ \\
\hline $\begin{array}{l}\text { Biaya } \\
\text { Operasion } \\
\text { al }\end{array}$ & $-1,735$ & ,346 &,- 880 & $\begin{array}{r}- \\
5,01 \\
0\end{array}$ & $\begin{array}{r}, 00 \\
4\end{array}$ & ,434 & $\begin{array}{r}2,30 \\
5\end{array}$ \\
\hline
\end{tabular}


a. Dependent Variable: Laba Bersih

Sumber: Data Olahan SPSS 25

\section{Uji Heteroskedastisitas}

Dari Gambar 1 menunjukkan terlihat titik-titik menyebar secara acak dan menyebar baik di bawah angka 0 pada sumbu Y. Oleh karena itu, dapat disimpulkan bahwa tidak terjadi heteroskedastisitas pada model regresi.

\section{Gambar 1. Uji Heteroskedastisitas}

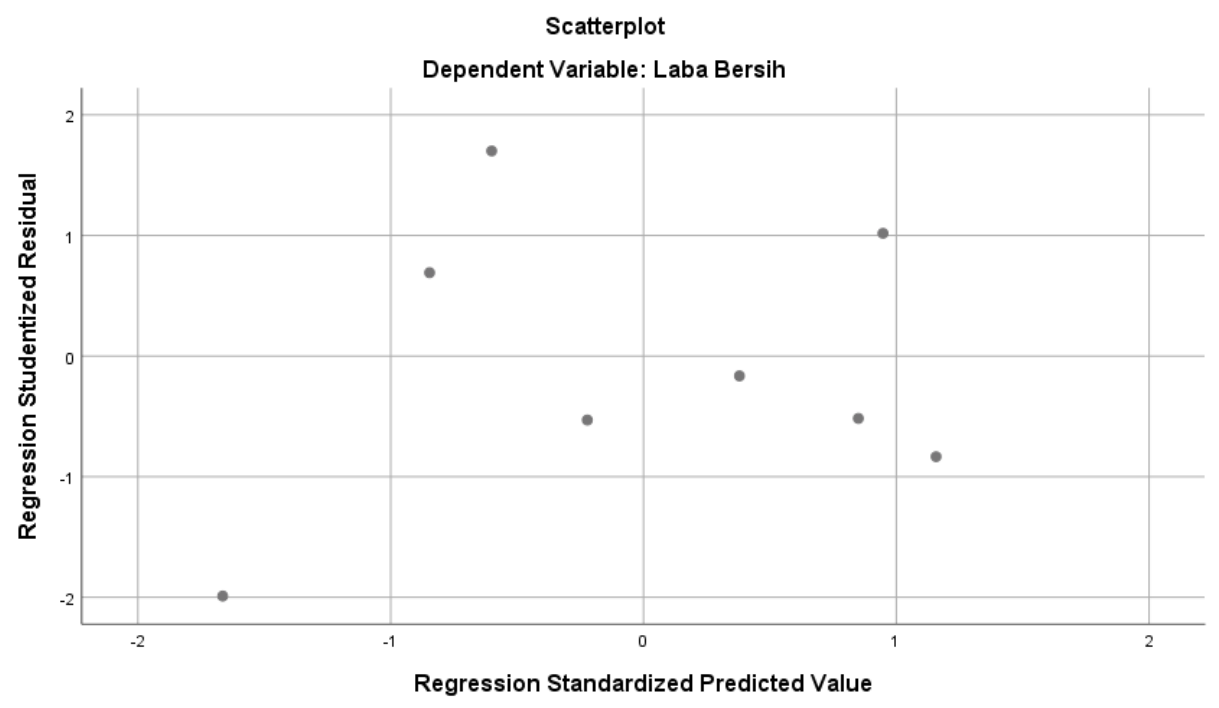

Sumber: Data Olahan SPSS 25

\section{Uji Autokorelasi}

Dari Tabel 4 menunjukkan nilai Asymp. Sig (2-tailed) sebesar 0,703 yang artinya > 0,05 menyatakan data yang digunakan cukup acak sehingga tidak terdapat autokorelasi.

\section{Tabel 4. Uji Autokorelasi}

Runs Test

\begin{tabular}{lr} 
& $\begin{array}{c}\text { Unstandardize } \\
\text { d Residual }\end{array}$ \\
\hline Test Value & a \\
\hline Cases $<$ Test Value & $-102010,24653$ \\
\hline Cases $>=$ Test Value & 4 \\
\hline Total Cases & 8 \\
\hline Number of Runs & 4 \\
\hline$Z$ &,- 382 \\
\hline Asymp. Sig. (2-tailed) &, 703 \\
\hline
\end{tabular}

a. Median

Sumber: Data Olahan SPSS 25

\section{Uji Korelasi}

Dari Tabel 5 dapat ditentukan analisa kriteria korelasi berdasarkan Tabel 3 .
Adapun kriteria korelasi menurut Sugiyono (2017:184) sebagai berikut: 
1. Korelasi penjualan (X1) dengan laba bersih (Y) sebesar 0,773 artinya sangat kuat;
2. Korelasi biaya operasional (X2) dengan laba bersih (Y) sebesar 0,119 artinya sangat kuat.

Tabel 5. Uji Korelasi

Correlations

\begin{tabular}{|c|c|c|c|c|}
\hline & & Penjualan & $\begin{array}{c}\text { Biaya } \\
\text { Operasional } \\
\end{array}$ & $\begin{array}{l}\text { Laba } \\
\text { Bersih } \\
\end{array}$ \\
\hline \multirow[t]{3}{*}{ Penjualan } & $\begin{array}{l}\text { Pearson } \\
\text { Correlation }\end{array}$ & 1 &, $752^{*}$ &, $773^{*}$ \\
\hline & Sig. (2-tailed) & & ,031 &, 025 \\
\hline & $\mathrm{N}$ & 8 & 8 & 8 \\
\hline \multirow[t]{3}{*}{$\begin{array}{l}\text { Biaya } \\
\text { Operasional }\end{array}$} & $\begin{array}{l}\text { Pearson } \\
\text { Correlation }\end{array}$ &, $752^{*}$ & 1 & , 199 \\
\hline & Sig. (2-tailed) & ,031 & & ,636 \\
\hline & $\mathrm{N}$ & 8 & 8 & 8 \\
\hline \multirow[t]{3}{*}{ Laba Bersih } & $\begin{array}{l}\text { Pearson } \\
\text { Correlation }\end{array}$ &, $773^{*}$ & , 199 & 1 \\
\hline & Sig. (2-tailed) & ,025 & ,636 & \\
\hline & $\mathrm{N}$ & 8 & 8 & 8 \\
\hline
\end{tabular}

*. Correlation is significant at the 0.05 level (2-tailed).

Sumber: Data Olahan SPSS 25

\section{Uji Koefisien Determinan $\left(\mathbf{R}^{2}\right)$}

\section{Tabel 6. Uji Koefisien Determinan $\left(\mathbf{R}^{2}\right)$ Model Summary ${ }^{b}$}

\begin{tabular}{ll|r|r|r} 
Model & R & R Square & $\begin{array}{c}\text { Adjusted R } \\
\text { Square }\end{array}$ & $\begin{array}{l}\text { Std. Error of } \\
\text { the Estimate }\end{array}$ \\
\hline 1 &, $966^{\mathrm{a}}$ &, 933 &, 906 & 342659,553 \\
\hline
\end{tabular}

a. Predictors: (Constant), Biaya Operasional, Penjualan

b. Dependent Variable: Laba Bersih

Sumber: Data Olahan SPSS 25

Tabel 6 memperlihatkan nilai $\mathrm{R}^{2}$ adalah sebesar 0,933. Hal ini berarti secara simultan laba bersih (Y) dipengaruhi oleh penjualan (X1) dan biaya operasional (X2) sebesar $93,3 \%$ dan sisanya $6,7 \%$ dipengaruhi oleh variabel lain yang tidak diteliti dalam penelitian ini.

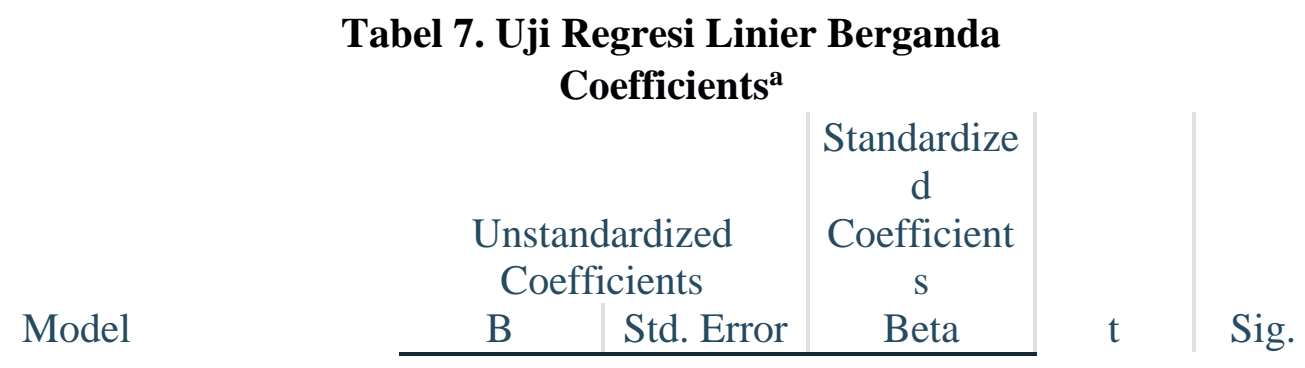




\begin{tabular}{l|r|r|r|r|r}
\hline (Constant) & $-730372,41$ & &,- 598 &, 576 \\
& 436785,45 & 3 & & & \\
\hline Penjualan & 9 & & & & \\
\hline Biaya & $-1,735$ &, 068 & 1,435 & 8,166 &, 000 \\
\hline Operasional & &, 346 &,- 880 & $-5,010$ &, 004 \\
\hline
\end{tabular}

a. Dependent Variable: Laba Bersih

Sumber: Data Olahan SPSS 25

\section{Analisi Regresi Linier Berganda}

Berdasarkan Tabel 7 diperoleh

model persamaan sebagai berikut :

$\mathrm{Y}=-436785,459+0,553 \mathrm{X}_{1}-1,735 \mathrm{X}_{2}$

Keterangan:

$\mathrm{Y}=$ Laba Bersih

$\mathrm{X}_{1} \quad=$ Penjualan

$\mathrm{X}_{2} \quad=$ Biaya Operasional

Dari hasil persamaan linier berganda tersebut dapat diinterpretasikan :

1. Nilai konstanta sebesar $-436785,459$ artinya jika variabel penjualan (X1) dan biaya operasional (X2) bernilai 0.00 (nol) maka laba bersih (Y) memiliki nilai sebesar $-436785,459$.

2. Nilai koefisien penjualan (X1) sebesar 0,553 bertanda positif. Hal ini menunjukkan penjualan (X1) memiliki hubungan yang searah dengan laba bersih (Y). Maka setiap kenaikan 1 angka penjualan (X1) berpengaruh naik pula terhadap laba bersih (Y) sebesar 0,553 dengan asumsi bahwa variabel bebas yang lain dari model regresi adalah tetap.

3. Nilai koefisien biaya operasional (X2) sebesar 1,735 bertanda negatif. Hal ini menunjukkan bahwa biaya operasional (X2) memiliki hubungan yang berlawanan dengan laba bersih (Y). Maka setiap kenaikan 1 angka biaya operasional (X2) berpengaruh menurun terhadap laba bersih (Y) sebesar 1,735 dengan asumsi bahwa variabel bebas yang lain dari model regresi adalah tetap.

\section{Uji Parsial (Uji t)}

Tabel 8. Uji Parsial (Uji t) Coefficients $^{\mathrm{a}}$

\begin{tabular}{|c|c|c|c|c|c|c|}
\hline \multirow{2}{*}{\multicolumn{2}{|c|}{ Model }} & \multicolumn{2}{|c|}{$\begin{array}{l}\text { Unstandardized } \\
\text { Coefficients }\end{array}$} & \multirow[t]{2}{*}{$\begin{array}{c}\text { Standardize } \\
\text { d } \\
\text { Coefficient } \\
\text { s } \\
\text { Beta } \\
\end{array}$} & \multirow[b]{2}{*}{$\mathrm{t}$} & \multirow[b]{2}{*}{ Sig. } \\
\hline & & B & Std. Error & & & \\
\hline 1 & (Constant) & 436785,459 & $\begin{array}{r}730372,41 \\
3 \\
\end{array}$ & &,- 598 & ,576 \\
\hline & Penjualan &, 553 &, 068 & 1,435 & 8,166 &, 000 \\
\hline & $\begin{array}{l}\text { Biaya } \\
\text { Operasional }\end{array}$ & $-1,735$ & ,346 &,- 880 & $-5,010$ & ,004 \\
\hline
\end{tabular}

a. Dependent Variable: Laba Bersih

Sumber: Data Olahan SPSS 25

Berdasarkan hasil uji signifikan parsial (Uji t) dapat disimpulkan: a. Hasil thitung penjualan (X1) sebesar 8,166 sedangkan tabel 2,57058 , maka 
nilai $t_{\text {hitung }}>t_{\text {tabel }}$. Sementara nilai signifikansi thitung variabel penjualan (X1) sebesar 0,000 artinya $<0,05$. Maka untuk H1 hasilnya adalah Ha diterima dan Ho ditolak karena terdapat pengaruh yang signifikan dimana penjualan (X1) secara parsial berpengaruh signifikan terhadap laba bersih (Y).

b. Hasil thitung biaya operasional (X2) sebesar $-5,010$ sedangkan $t_{\text {tabel }}$ -
2,57058, maka nilai $-\mathrm{t}_{\text {hitung }}<-\mathrm{t}_{\text {tabel }}$. Sementara nilai signifikansi $t_{\text {hitung }}$ variabel biaya operasional (X2) sebesar 0,004 artinya $<0,05$. Maka untuk $\mathrm{H} 2$ hasilnya adalah Ha diterima dan Ho ditolak karena terdapat pengaruh yang signifikan dimana biaya operasional (X2) secara parsial berpengaruh signifikan terhadap laba bersih (Y).

Tabel 9. Uji Simultan (Uji F)

ANOVA ${ }^{a}$

\begin{tabular}{llr|r|r|r|r}
\multicolumn{1}{l}{ Model } & Sum of Squares & df & Mean Square & F & Sig. \\
\hline $1 \quad$ Regression & 8177619673800,2 & 2 & 4088809836900, & 34,82 & \multirow{2}{*}{, $001^{\mathrm{b}}$} \\
\hline Residual & 587077847477,62 & 5 & 117415569495,5 & 3 & \\
\hline Total & 8764697521277,8 & 7 & 25 & & \\
\hline & 74 & & & & \\
\hline
\end{tabular}

a. Dependent Variable: Laba Bersih

b. Predictors: (Constant), Biaya Operasional, Penjualan

Sumber: Data Olahan SPSS 25

\section{Uji Simultan (Uji F)}

Dari Tabel 9 terlihat bahwa secara simultan pengaruh penjualan (X1) dan biaya operasional (X2) terhadap laba bersih (Y) dapat dilihat bahwa $\mathrm{F}_{\text {hitung }}$ sebesar 34,823 dan $F_{\text {tabel }}$ sebesar 5,14 maka $\mathrm{F}_{\text {hitung }}>\mathrm{F}_{\text {tabel }}$ atau $\mathrm{P}$ value $<\alpha$ yaitu $34,823>5,14$ dan $0.001<0.05$. Maka untuk $\mathrm{H} 3$ hasilnya adalah $\mathrm{Ha}$ diterima dan Ho ditolak karena terdapat pengaruh yang signifikan dimana penjualan (X1) dan biaya operasional (X2) secara simultan berpengaruh signifikan terhadap laba bersih (Y).

\section{Pengaruh Penjualan Terhadap Laba Bersih}

Berdasarkan hasil uji hipotesis penjualan memperoleh $t_{\text {hitung }}$ sebesar $=$ 8,166 sedangkan $t_{\text {tabel }}=2,57058$, sedangkan nilai signifikansi sebesar 0,000 artinya $<0,05$. Hasil dari $\mathrm{H} 1$ adalah $\mathrm{Ha}$ diterima dan Ho ditolak karena terdapat pengaruh yang signifikan, artinya secara parsial penjualan berpengaruh terhadap laba bersih pada PT Indocement Tunggal Prakarsa (Persero) Tbk. periode 20102017.

Hasil H1 sependapat dengan Munawir (2014:184), salah satu langkah untuk mendapat laba yang besar (laba bersih) adalah dengan memperhatikan besar kecilnya penjualan. Hasil peneltian ini juga sejalan dengan penelitian Akbar \& Astuti (2017) menyatakan bahwa penjualan dan berpengaruh pada laba bersih, dan ketika penjualan meningkat maka laba bersih akan ikut meningkat pula, sedangkan ketika penjualan menurun maka laba bersih akan ikut turun.

\section{Pengaruh Biaya Operasional Terhadap Laba Bersih}

Berdasarkan hasil uji hipotesis biaya operasional memperoleh thitung $=-5,010$ sedangkan $t_{\text {tabel }}=-2,57058$, sedangkan nilai 
signifikansi 0,004 artinya $<0,05$. Maka untuk $\mathrm{H} 2$ hasilnya adalah Ha diterima dan Ho ditolak karena terdapat pengaruh yang signifikan dan biaya operasional berpengaruh signifikan terhadap laba bersih pada PT Indocement Tunggal Prakarsa (Persero) Tbk periode 20102017. Hasil H2 sependapat dengan teori Jusuf (2014:35) yang menyatakan, besar kecilnya biaya operasional memengaruhi laba bersih yang didapat. Penelitian ini mendukung penelitian sebelumnya Risyana \& Suzan (2018) yang membuktikan bahwa biaya operasional berpengaruh terhadap laba bersih, dan apabila semakin tinggi biaya operasional yang ada di perusahaan maka laba bersih akan mengalami penurunan dan juga sebaliknya.

\section{Pengaruh Penjualan dan Biaya Operasional Terhadap Laba Bersih}

Berdasarkan hasil uji hipotesis simultan memperoleh nilai $\mathrm{F}_{\text {hitung }}=$ 34,823 sedangkan $F_{\text {tabel }}=5,14$, maka $\mathrm{F}_{\text {hitung }}>\mathrm{F}_{\text {tabel }}$ dengan nilai signifikansi $0,001<0,05$. Hasil dari H3 adalah Ha diterima dan Ho ditolak karena terdapat pengaruh yang signifikan, artinya penjualan dan biaya operasional secara simultan berpengaruh terhadap laba bersih pada PT Indocement Tunggal Prakarsa (Persero) Tbk. periode 2010-2017.

Penelitian ini sesuai dengan pendapat Rahardjo (2015) yang menyatakan, adanya hubungan yang erat mengenai volume penjualan terhadap peningkatan laba bersih perusahaan, karena dalam hal ini laba akan timbul jika penjualan produk lebih besar dibandingkan dengan biaya-biaya yang dikeluarkan. Penelitian ini juga didukung oleh penelitian Wisesa, Zukhri, \& Suwena (2014) yang menyatakan, volume penjualan dan biaya operasional mempunyai pengaruh terhadap laba bersih. Dikatakan bahwa untuk meningkatkan laba bersih, maka volume penjualan pada suatu perusahaan harus meningkat juga dan biaya harus efisien, serta biaya tersebut harus lebih tinggi dari pendapatan yang diperoleh.

Laba akan mengalami peningkatan jika ada peningkatan penjualan dan biaya produksi, artinya semakin besar biaya produksi dikeluarkan akan menambah jumlah produksi sehingga potensi penjualan akan menaikkan laba, tetapi jika peningkatan biaya produksi tidak diimbangi dengan peningkatan penjualan maka akan mengakibatkan perusahaan mengalami penurunan laba.

\section{Kesimpulan}

Berdasarkan hasil analisis dan pembahasan, maka diperoleh simpulan bahwa penjualan pada PT Indocement Tunggal Prakarsa (Persero) Tbk periode 2010-2017 berpengaruh pada laba bersih, karena apabila penjualan naik maka laba bersih akan ikut naik pula, demikian juga sebaliknya apabila penjualan turun maka laba bersih akan turun. Biaya operasional pada PT Indocement Tunggal Prakarsa (Persero) Tbk periode 2010-2017 berpengaruh pada laba bersih, apabila biaya operasional tinggi maka laba bersih akan semakin mengalami penurunan, dan jika biaya operasional bisa ditekan serendah mungkin akan berdampak pada kenaikan laba bersih. Kemudian penjualan dan biaya operasional pada PT Indocement Tunggal Prakarsa (Persero) Tbk periode 2010-2017 berpengaruh pada laba bersih, untuk mendapatkan laba yang diharapkan ada keterkaitan antara peningkatan penjualan dengan efesiensi biaya operasional.

Saran setelah dilakukan penelitian ini adalah antara lain, dalam upaya meningkatkan laba yang maksimal perusahaan harus bisa meningkatkan penjualan, salah satunya dengan mengurangi beban penjualan. Saran kedua yaitu diharapkan perusahaan agar memperhatikan dan mampu menekan biaya operasionalnya dengan seefisien mungkin sehingga bisa meningkatkan laba bersih. Dengan menekan biaya produksi dapat juga menekan harga jual sehingga 
mampu bersaing dengan perusahaan yang sejenis, dan dampaknya akan menaikkan penjualan, dengan meningkatnya penjualan menjadikan pula peningkatan laba bersih.

\section{Daftar Pustaka}

Akbar, A. S., \& Astuti, W. A. (2017). Pengaruh Penjualan dan Biaya Produksi terhadap Laba Bersih (Survei pada Perusahaan Manufaktur Sektor Aneka Idustri Sub Sektor Otomotif dan Komponen yang Terdaftar di Bursa Efek Indonesia (BEI) Tahun 2011-2016). Skripsi. Universitas Komputer Indonesia Bandung.

Ayuningtyas, D. (21 Maret 2019). Empat Tahun Berturut-turut Laba Indocement Turun. CNBC Indonesia. Diakses dari https://www.cnbcindonesia.com/ma rket/20190321113028-1762035/empat-tahun-berturut-turutlaba-indocement-turun

Butar, B. M. (2018). Pengaruh Penjualan Terhadap Laba Bersih Pada PT. Biosafe Indonesia Medan. Jurnal Neraca Agung, 17(1), 65-75.

Fitrihartini S, A. (2016). Pengaruh Volume Penjualan dan Biaya Operasional terhadap Laba Bersih (Studi Kasus Pada Perusahaan Batubara yang Terdaftar di Bursa Efek Indonesia Periode 2011-2014). Skripsi. Universitas Komputer Indonesia Bandung.

Ghozali, I. (2016). Aplikasi Analisis Multivariete Dengan Program IBM SPSS 23 (Edisi 8). Semarang: Badan Penerbit Universitas Diponegoro.

(2017). Aplikasi Analisis Multivariete Dengan Program IBM SPSS 23. Semarang: Badan Penerbit Universitas Diponegoro.

Hery, H. (2013). Akuntansi Keuangan
Menengah. Yogyakarta: CAPS.

Hery, H. (2016). Analisis Laporan Keuangan. Jakarta: Grasindo.

Jusuf, J. (2014). Analisis Kredit Untuk Account Officer. Jakarta: PT. Gramedia.

Kasmir, K. (2014). Analisis Laporan Keuangan, Edisi Satu. Jakarta: PT Raja Grafindo Persada.

Kertiyasa, M. B. (23 Maret 2018). Laba Indocement Turun Tajam 51\% jadi Rp 1,85 Triliun. Okezone Indonesia. Diakses dari https://economy.okezone.com/read/ 2018/03/23/278/1876994/labaindocement-turun-tajam-51-jadirp1-85-triliun

Kurniawan, A. (2014). Metode Riset untuk Ekonomi \& Bisnis. Bandung: Alfabeta.

Moekijat, M. (2014). Manajemen Sumber Daya Manusia. Bandung: Mandar Maju.

Munawir, S. (2014). Analisis Laporan Keuangan. Yogyakarta: Liberty.

Muria, G. (2018). Pengaruh Pendapatan dan Biaya Operasional terhadap Laba Bersih (Studi Kasus pada Perusahaan Manufaktur Sektor Industri Dasar dan Kimia yang Terdaftar di BEI Periode 20122016). E-Qien: Jurnal Ekonomi dan Bisnis, 5(1), 19-33. doi: https://doi.org/10.34308/eqien.v5i1. $\underline{11}$

Murhadi, W. R. (2013). Analisis Laporan Keuangan, Proyeksi dan Valuasi Saham. Jakarta: Salemba Empat.

PT Indocement Tunggal Prakarsa (Persero) Tbk. (2019). 2010-2017 annual report. Diakses dari https://www.idx.co.id/perusahaantercatat/laporan-keuangan-dantahunan/ 
Rahardjo, B. (2015). Keuangan dan Akuntansi untuk Manajer Non Keuangan, Edisi Pertama. Yogyakarta: Graha Ilmu.

Riduwan, R., \& Akdon, A. (2013). Rumus dan Data dalam Analisis Statistika. Bandung: Alfabeta.

Risyana, R., \& Suzan, L. (2018). Pengaruh Volume Penjualan Dan Biaya Operasional Terhadap Laba Bersih (Studi Pada Perusahaan Manufaktur Subsektor Makanan Dan Minuman Yang Terdaftar Di Bursa Efek Indonesia Periode 20142016). E-Proceeding of Management (pp. 2449-2459). Telkom University. Diakses dari https://openlibrary.telkomuniversity .ac.id/pustaka/files/143625/jurnal_e proc/pengaruh-volume-penjualandan-biaya-operasional-terhadaplaba-bersih-studi-pada-perusahaanmanufaktur-makanan-danminuman-yang-terdaftar-di-bursaefek-indonesia-periode-2014-2016.pdf

Satwika, F., Hendratno, H., \& Zultilisna, D. (2018). Pengaruh Harga Pokok Produksi, Biaya Operasional, dan Penjualan Bersih terhadap Laba Bersih (Studi Kasus pada Perusahaan Sektor Industri Tekstil dan Garmen yang Terdaftar di Bursa Efek Indonesia Tahun 2012-2016). E-Proceeding of Management (pp. 2154-2163). Telkom University. Diakses dari https://libraryeproceeding.telkomun iversity.ac.id/index.php/managemen t/article/view/6793

Sugiyono, S. (2017). Metode Penelitian Pendidikan (Pendekatan Kuantitatif, Kualitatif dan $R \& D)$. Bandung: Alfabeta.

Sujarweni, V. W. (2015). SPSS untuk Penelitian. Yogyakarta: Pustaka Baru Press.
Sulistyowati, L. (2010). Memahami Laporan Keuangan. Jakarta: Elex Media Komputindo.

Tjiptono, F., \& Chandra, G. (2012). Pemasaran Strategik. Yogyakarta.

Widilestariningtyas, O., Waluya, D., \& Anggadini, S. A. (2012). Akuntansi Biaya. Yogyakarta: Graha Ilmu.

Wisesa, I. W. B., Zukhri, A., \& Suwena, K. R. (2014). Pengaruh Volume Penjualan Mente dan Biaya Operasional terhadap Laba Bersih pada UD Agung Esha Tahun 2013. Jurnal Pendidikan Ekonomi Undiksha, 4(1). doi: http://dx.doi.org/10.23887/jjpe.v4i1 .3293 